\title{
The Realization of People's Sovereignty Through Recall of People to Elected Legislative Members
}

\author{
Lukman Nulhakim* ${ }^{*}$ and Siti Rodhiyah Dwi Istinah**) \\ ${ }^{*}$ Student of Master of Law, Faculty of Law, Universitas Islam Sultan Agung \\ Semarang, Email : lukmannulhakim83@yahoo.co.id \\ $\left.{ }^{* *}\right)$ Lecturer of Master of Law, Faculty of Law, Universitas Islam Sultan Agung \\ Semarang
}

\begin{abstract}
The purpose of this study is to analyze the recalling system of legislative members in Indonesia that does not reflect the value of Pancasila justice; as well as obstacles and solutions to the recalling of legislative members in Indonesia that fulfill a sense of justice and Pancasila values. The research method used is an empirical juridical approach. Research conclusions is the recalling system for legislative members in Indonesia has not reflected the value of Pancasila justice, especially the four principles of Pancasila, namely democracy led by wisdom/deliberation, and eliminating the election system based on Open Proportionality, where constituents do not choose parties but elect candidates. Obstacles in recalling legislative members in Indonesia restrain legislative members from voicing their opinions and their efforts to fulfill the demands of their constituents and their nation, and make legislators no longer become representatives of the people but merely party officials. Recalling members of the legislature should be returned to the sovereignty of the people through the General Election Commission which determines and determines the elected legislative member, whether an elected legislative member can be recalled by his party or not, and as a form of people's sovereignty, regulations should be made regarding terms, conditions and procedures of people from the electoral area of elected legislative members to be able to recall the legislative members who are representing them to the General Election Commission, and if there is a dispute between the people recalling the recalled members or their political parties, the dispute can be carried out through the Constitutional Court or Supreme Court.

Keywords: Embodiment; Sovereignty; People; Recall; Legistative.
\end{abstract}

\section{Introduction}

The 1945 Constitution Article 1 Paragraph (1) which states "The State of Indonesia is a Unitary State in the form of a Republic" Article 1 paragraph (2) "Sovereignty rests in the hands of the people and is exercised according to the Constitution" and Article 1 paragraph (3) which reads "Indonesia is a constitutional state". ${ }^{1}$

Etymologically, "Democracy" consists of two words that come from Greek, namely demos which means people or residents of a place, and cratein or cratos which means power or sovereignty. So, demos-cratein or demos-cratos (democracy) is a state of state where in the system of government, sovereignty is in the hands of the people,

\footnotetext{
${ }^{1}$ Dedi Mulyadi. (2012). Kebijakan Legislasi, Tentang Sanksi Pidana Pemilu Legislatif Di Indonesia Dalam Perspektif Demokrasi, Gramata Publishing, Jakarta, p. 1. See Rida Farida, "Mekanisme Penggantian Antar Waktu Anggota Dewan Perwakilan Rakyat dan Implikasinya Dalam Konsep Perwakilan Rakyat", Jurnal Cita Hukum, Vol. 1. No. 2. December 2013, Website: www.fsh-uinjkt.net, E-mail: jurnal.citahukum@uinjkt.ac.id., Permalink: http://journal.uinjkt.ac.id/index.php/citahukum , p. 196.
} 
the highest power is in joint decisions of the people, the people are in power, the people's government and power by the people. ${ }^{2}$

Democracy is a form of government in which all citizens have equal rights in making decisions that can change their lives. Democracy allows citizens to participate either directly or through representation in the formulation, development and making of laws. Democracy includes social, economic, and cultural conditions that allow the practice of political freedom freely and equally. ${ }^{3}$

Democracy is also an evolutive and dynamic concept. This means that the concept of democracy is always changing, both in its formal forms and in substance, in accordance with the socio-historical context and dynamics in which the concept of democracy is born and develops. Democracy develops evolutionarily, slowly but surely. What was understood as democratic ideas in Ancient Greece, for example, does not always have to be in accordance with and relevant to the ideas of democracy that are developing today. For this reason, democracy has always been debated whether democracy is universal or specific. ${ }^{4}$

The meaning of democracy as the basis for living in a society and a state implies that it is the people who provide provisions in matters concerning their lives, including in assessing State policies, because these policies will determine the lives of the people. A country that adopts a democratic system is a country that is organized based on the will and will of the people. From an organizational point of view, democracy means organizing the State by the people themselves or with the consent of the people because sovereignty is in the hands of the people. ${ }^{5}$

A country that adheres to democracy at least there are several things that absolutely exist, namely requiring general elections, rotation or regeneration of national leadership, independent judicial power, representation of people's sovereignty through strong and independent parliamentary institutions, respect and guarantee of human rights, and a constitution that guarantees that these things work. ${ }^{6}$

A democratic state certainly justifies the existence of political parties as a pillar of democracy or the exercise of people's sovereignty. Political parties basically have a central and important position (status) and role in every democratic system because they play an important role as a liaison between the state government and its people (the citizens). ${ }^{7}$

Political parties are pillars of democracy. If this pillar is no longer trusted by the people, it will pose a serious threat to the sustainability of democracy in Indonesia. Thus, returning political parties to the right path in the flow of democratization in Indonesia is the responsibility of all of us. Political parties are also not only organizations where

\footnotetext{
${ }^{2}$ Ibid.p. 131.

${ }^{3}$ https://id.wikipedia.org/wiki/Demokrasi accessed on October 20, 2020 at 12:15.

${ }^{4}$ A.Muchtar Ghazali Abdul Majid. (2016). PPKn Materi Kuliah Perguruan Tinggi Islam. Bandung: Remaja Rosda Karya.p. 130.

${ }^{5}$ Ibid.p. 133.

${ }^{6}$ Miriam Budiardjo. (1992). Dasar-dasar Ilmu Politik, Edition-14, Jakarta: Gramedia Pustaka Utama. p. 60.

7 Jimly Asshiddiqie. (2007). Pokok-Pokok Hukum Tata Negara Indonesia Pasca Reformasi. Jakarta: BIP. p.710.
} 
politicians gather, but can also carry out their functions for the benefit of society. Thus in a democratic system, parties play a very important role.

General election is one way to determine the people's representatives who will sit in the people's representative body. Becoming a political representative within the framework of a democratic system carries a relatively large burden and responsibility as well as political consequences. Therefore, in addition to legal traps due to violations of laws and regulations that can be materially proven in public courts, members of parliament face the challenge of being sued politically by both their parent political party and constituents and society in general. ${ }^{8}$ In fact, Indonesia tends to adopt a diversification model in which DPR members are representatives of political parties. This means that DPR members must represent the interests of political parties and give voice to political parties. The existence of the Inter-Time Replacement system (PAW) used by political parties against DPR members who come from the political parties concerned strengthens this, even though when referring to the MK-RI decision Number 008/PUU-IV/2006, in an electoral system where elections directly choosing someone's name as a representative, it is logical if the reccal is carried out by voters, for example through a petition mechanism. Whereas in the electoral system by selecting political parties in terms of the election of DPR and DPRD members, it is also logical that the recall is carried out by the nominating political party.

The definition of recall in Indonesia is different from the definition of recall in the United States. In the United States the term recall is the complete Recall Election which is used to declare the right of the voters (constituents) to remove representatives of the people before their term ends. ${ }^{9}$ Interim Replacement (PAW) developed since 1903 in California, there were 117 attempts to overthrow the Members of the legislature. There were 7 times that reached the voting of the voters, but none of them were successful. In general, citizens of the United States believe that a legislative term of only two years is not sufficient to judge a person's success. If a representative is deemed unsuccessful then he will not be re-elected. Intertime Replacement (PAW) for executives only succeeded in deposing North Dakota Governor Lynn J.Frazier in 1921 and California Governor Gray Davis in 2003. ${ }^{10}$

The purpose of this study was to analyze: 1) the recalling system for legislative members in Indonesia does not yet reflect the value of Pancasila justice; and 2) obstacles and solutions to the recalling of legislative members in Indonesia that fulfill a sense of justice and Pancasila values.

\section{Research methods}

The research method as a science is always based on empirical facts in society. The empirical facts are worked out methodically, arranged systematically, and described in a logical and analysis manner. The focus of research is always directed at discovering

\footnotetext{
${ }^{8}$ Sebastian Salang. (2009). Menghindari Jeratan Hukum Bagi Anggota Dewan, Jakarta: PT. Penebar Swadaya. p. 269.

${ }_{9}^{9}$ Ananda B. Kusuma. (2006). Jurnal Konstitusi Volume 3 Nomor 4 Tentang Recall, Jakarta: MK RI. p. 156.

10 http://www.hukumonline.com/ Mempertanyakan Hegemoni Penggantian Antar Waktu (PAW) Anggota DPR di Tangan Partai Politik, accessed on December 19, 2020.
} 
new things or developing existing knowledge. ${ }^{11}$ The method used for this research uses an empirical juridical approach. The juridical approach is an approach in terms of statutory regulations and legal norms in accordance with existing problems, while the empirical approach is to emphasize research aimed at obtaining knowledge of laws and regulations concerning research problems based on existing facts. ${ }^{12}$ The specifications in this research include descriptive analysis, namely describing in detail, systematically and thoroughly all matters relating to the realization of people's sovereignty through the people's recall of elected legislative members, the research was conducted in the Cirebon jurisdiction.

The analytical method used is a qualitative method, to obtain views on the implementation of laws and regulations in Indonesia regarding the realization of people's sovereignty through people's recall.

\section{Results and Discussion}

\subsection{Recalling Legislative Members in Indonesia Have Not Reflected the Value of Pancasila Justice}

The discussion about justice develops with different approaches and points of view, so that because of this, the theories of justice have also developed from scholars who essentially put forward their theories from their respective points of view. In Indonesia, justice is described in Pancasila as the basis of the state, namely social justice for all Indonesian people. ${ }^{13}$ The values contained in the principles of social justice for all Indonesian people are based on and are inspired by the principles of Pancasila. ${ }^{14}$

Based on the principles of Pancasila, the fifth principle contains the values of justice that must be manifested in a common life (social life). As for justice is based on and imbued with the essence of human justice, namely justice in the relationship between man and himself, man with other human beings, man with society, nation and state, and human relationship with God. ${ }^{15}$

The basic provisions of the dismissal of members of the DPR are contained in Article 22 B of the 1945 Constitution of the Republic of Indonesia which reads "Members of the House of Representatives can be dismissed from their posts, whose terms and procedures are regulated in law" which is then further regulated in the Law. Act No. 17 of 2014 concerning the People's Consultative Assembly, People's Representative Council, Regional Representative Council, and Regional People's Representative Council (MD3) and Act No. 2 of 2008 concerning Political Parties.

Interim Replacement (PAW) was abolished based on the provisions of Act No. 4 of 1999 concerning the Composition and Position of the People's Consultative Assembly, the People's Representative Council, and the Regional People's Representative Council.

\footnotetext{
${ }^{11}$ Abdul Kadir Muhammad. (2004). Hukum Dan Penelitian Hukum, Bandung: Cipta Aditya Bakti. p. 57.

12 Ronny Hanitijo Soemito. (1990). Metode Penelitian Hukum Dan Jurimetri, Jakarta: Ghalia Indonesia. p. 40.

${ }^{13}$ Agus Santoso H.M. (2012). Hukum, Moral, dan Keadilan, Jakarta: Kencana Prenada Media Group. p.86.

14 Ibid.

${ }^{15}$ Kaelan. (2007). Pendidikan Kewarganegaraan Untuk Perguruan Tinggi, Yogyakarta: Paradigma. p. 36.
} 
The elimination of interim replacement (PAW) is an impact in order to strengthen parliament. However, this has become a polemic, because a number of legislators who have committed inappropriate acts, such as changing political parties, committing immoral acts, or violating the code of ethics did not receive strict sanctions. Meanwhile, the public demands for accountable board members, both in terms of their political performance and ethical behavior. Therefore Inter-Time Replacement (PAW) was re-emerged as regulated in Act No. 27 of 2009 concerning the People's Consultative Assembly, People's Representative Council, Regional Representative Council and Regional People's Representative Council and Act No. 2 of 2008 concerning Political Parties. But along the way, this authority over time replacement (PAW) was misinterpreted by party leaders. Members of the council who disagree with the party are sanctioned and dismissed through the Inter-Time Replacement (PAW) mechanism, so they are known as party officers who must upright voice the party's votes, not the people's votes. Even though these council members should voice the aspirations of the people. Members of the council who disagree with the party are sanctioned and dismissed through the Inter-Time Replacement (PAW) mechanism, so they are known as party officers who must upright voice the party's votes, not the people's votes. Even though these council members should voice the aspirations of the people. Members of the council who disagree with the party are sanctioned and dismissed through the Inter-Time Replacement (PAW) mechanism, so they are known as party officers who must upright voice the party's votes, not the people's votes. Even though these council members should voice the aspirations of the people.

During the New Order government, a number of political parties had made Intertime Replacement (PAW) against their party members in parliament. Likewise, after the fall of the New Order, replaced by the Reformation Order, the mechanism of Inter-Time Replacement (PAW) by political parties occurred in cases such as the case of Lily Wahid and Effendy Choirie which in 2011 were recalled by their political party, namely the National Awakening Party (PKB) because they were against party decisions in terms of decision making related to the Century Bank case and the tax mafia case.

Based on these theoretical descriptions and empirical facts, it is concluded that the recalling system for legislative members in Indonesia has not reflected the value of Pancasila justice, especially the four principles of Pancasila, namely democracy led by wisdom/deliberation, and eliminating the Election system based on Open Proportionality, where constituents do not elect parties but elect candidates. Obstacles in recalling legislative members in Indonesia restrain legislators from voicing their opinions and their efforts to fulfill the demands of their constituents and their nation, and make legislators no longer become representatives of the people but merely party officials.

\subsection{Constraints and Solutions for Recalling Legislative Members in Indonesia Who Fulfill the Sense of Justice and Pancasila Values}

Sovereignty is usually understood from the translation of words such as "sovereignty", "soverainette", "sovereigniteit", "souvereyn", "superanus", "summa potestas", "maiestas" (majesty) and others adopted from English, French. , Germany, and the Netherlands, which are heavily influenced by Latin. All of these words refer to the 
notion of supreme power within or from a country which in English is called "sovereignfy". ${ }^{16}$ Sovereignty is a characteristic or legal attribute of countries, and as an attribute of a country it has been around for a long time, some even argue that sovereignty may be older than the concept of the state itself. ${ }^{17}$

Meanwhile, according to $\mathrm{JJ}$ Rousseau, the concept of sovereignty is populist and is based on the common will (volente generale) of the people who are incarnated through legislation. Therefore, according to him, the concept of sovereignty has 4 characteristics, namely. ${ }^{18}$

- Unity (united);

- Round, undivided (indivisibilite);

- Should not be submitted (inalienabilite);

- Remains unchanged (imprescriptibilite).

The seat of a person in a representative institution, whether due to appointment or through a general election, results in a relationship between the representative and the representative. The formation of representative institutions is also due to the existence of two well-known classical theories about the nature of the relationship between representatives and representatives, namely the theory of mandate and the theory of freedom. ${ }^{19}$

It can be said that representation is a concept that indicates a relationship between the representative and the party represented in which case the representative has a number of powers obtained by agreement with the party he represents.

Recallingor also called the change between times (PAW) by political parties, there are several things that need to be reviewed, especially the incompatibility of its application in the government system in Indonesia. Among them are First, there are no clear parameters related to recall by political parties. Second, the recall mechanism by political parties indicates the inconsistency of the paradigm of the people's sovereignty system that was built through elections. Third, granting recall rights to political parties does not prioritize the rule of law principle and is contrary to the principle of open proportionality in the election. Fourth, there is a judicial review on recall as evidence of disagreement with the provisions of recall in Indonesia. Fifth, recall by political parties has the potential to abuse and limit the functions of the DPR RI. The practice of implementing recall in Indonesia has not involved the people.

Recalling Legislative members should be returned to the people's sovereignty through the General Election Commission which determines and determines the elected legislative members, whether an elected legislative member can be recalled by his party or not, and as a form of people's sovereignty, regulations should be made regarding the terms, conditions and procedures of the people. from the electoral area of the elected legislative member to be able to recall the legislative member who is

\footnotetext{
${ }^{16}$ Djauhari, "Kedaulatan Rakyat Dalam Perspektif Islam", Jurnal Hukum, Vol. XV. No. 2, September 2005, p. 210.

${ }^{17}$ Fred Isywara. (1964). Pengantar Ilmu Politik, Bandung : Dhwiwantar. p. 92.

18 Ibid. p. 62-63.

19 Dahlan Thaib. (2000). DPR Dalam Sistem Ketatanegaraan Indonesia, Second Edition, Print-1. Yogyakarta: Liberty. p. 2.
} 
representing the people to the General Election Commission, and if there is a dispute between the people recalling the recalled member or their political party, the dispute can be carried out through the Constitutional Court or the Supreme Court.

\section{Closing}

The recalling system for legislative members in Indonesia has not reflected the value of Pancasila justice, especially the four principles of Pancasila, namely democracy led by wisdom/deliberation, and eliminating the Election system which is based on Open Proportionality, where constituents do not choose parties but elect candidates. Obstacles in recalling legislative members in Indonesia restrain legislators from voicing their opinions and their efforts to fulfill the demands of their constituents and their nation, and make legislators no longer become representatives of the people but merely party officials. The solution to the recall of legislative members in Indonesia that fulfills the sense of justice and Pancasila values is to return the recalling of legislative members to the people as the owner of sovereignty.

Recalling Legislative members should be returned to the people's sovereignty through General Election Commission which determines and determines the elected legislative members, whether an elected legislative member can be recalled by his party or not, and as a form of people's sovereignty, regulations should be made regarding the terms, conditions and procedures of the people from the electoral area of the elected legislative member to be able to recall the legislative member who is representing the people to the General Election Commission, and if there is a dispute between the people recalling the recalled member or their political party, the dispute can be carried out through the Constitutional Court or the Supreme Court.

\section{References}

\section{Journal and Internet:}

[1] Ananda B. Kusuma, 2006, Jurnal Konstitusi Volume 3 Nomor 4 Tentang Recall, MK RI, Jakarta.

[2] Djauhari, "Kedaulatan Rakyat Dalam Perspektif Islam", Jurnal Hukum, Vol. XV. No. 2, September 2005.

[3] https://id.wikipedia.org/wiki/Demokrasi accessed on 20 October 2020 at 12:15.

[4] http://www.hukumonline.com/Mempertanyakan Hegemoni Penggantian Antar Waktu (PAW) Anggota DPR di Tangan Partai Politik, accessed on 19 December 2020

[5] Rida Farida, "Mekanisme Penggantian Antar Waktu Anggota Dewan Perwakilan Rakyat dan Implikasinya Dalam Konsep Perwakilan Rakyat", Jurnal Cita Hukum, Vol. 1. No. 2. December 2013, Website: www.fsh-uinjkt.net, E-mail: jurnal.citahukum@uinjkt.ac.id., Permalink: http://journal.uinjkt.ac.id/index.php/citahukum.

\section{Books:}

[1] Agus Santoso, H.M. (2012). Hukum, Moral, dan Keadilan. Jakarta: Kencana Prenada Media Group 
[2] Abdul Kadir Muhammad. (2004). Hukum Dan Penelitian Hukum. Bandung: Cipta Aditya Bakti

[3] Dahlan Thaib. (2000). DPR Dalam Sistem Ketatanegaraan Indonesia, Second Edition, Print.1. Yogyakarta: Liberty

[4] Dedi Mulyadi. (2012). Kebijakan Legislasi, Tentang Sanksi Pidana Pemilu Legislatif Di Indonesia Dalam Perspektif Demokrasi. Jakarta: Gramata Publishing

[5] Fred Isywara. (1964). Pengantar Ilmu Politik. Bandung: Dhwiwantar

[6] Jimly Asshiddiqie. (2007). Pokok-Pokok Hukum Tata Negara Indonesia Pasca Reformasi. Jakarta: BIP

[7] Kaelan. (2007). Pendidikan Kewarganegaraan Untuk Perguruan Tinggi, Yogyakarta: Paradigma

[8] Miriam Budiardjo. (1992). Dasar-dasar Ilmu Politik, Print-14, Jakarta: Gramedia Pustaka Utama

[9] Muchtar Ghazali Abdul Majid, A. (2016). PPKn Materi Kuliah Perguruan Tinggi Islam. Bandung: Remaja Rosda Karya

[10] Ronny Hanitijo Soemito. (1990). Metode Penelitian Hukum Dan Jurimetri. Jakarta: Ghalia Indonesia

[11] Sebastian Salang. (2009). Menghindari Jeratan Hukum Bagi Anggota Dewan. Jakarta: PT. Penebar Swadaya 